\title{
Factors associated with anemia among Sri Lankan primary school children in rural North Central Province
}

Gayani Shashikala Amarasinghe*, Naotunna Palliya Guruge Chamidri Randika Naottunna,

Thilini Chanchala Agampodi and Suneth Buddhika Agampodi

\begin{abstract}
Background: Despite interventions, childhood anemia is still a major public health problem in low and middle income countries. Purpose of the present study is to determine factors associated with anemia among rural primary school children in Sri Lanka, a country undergoing rapid socioeconomic changes.
\end{abstract}

Methods: Multi stage cluster sampling was used to select 100 rural schools in NCP and a maximum of 50 children aged 60-131 months were enrolled from each school. Self-administered questionnaires were sent to parents. Anthropometric measurements and blood samples were obtained by trained investigators. Blood reports were analyzed in a commercial laboratory with external quality control measures.

Results: Total of 4412 children were included in the analysis. A Multiple regression was performed for hemoglobin. Only $4.2 \%$ of the change in hemoglobin could be explained by the model. District $(p>0.001)$, age $(p>0.001)$, timing of warm treatment $(p=0.026)$ and BMl for age $(p=0.002)$ uniquely contributed $1.12 \%, 1.19 \%, 0.13 \%$ and $0.26 \%$ to change in hemoglobin level respectively whereas, sex, monthly family income and frequency of meat and green leaf consumption didn't contribute significantly.

Peripheral blood film analyses were available for 146 anemic children. Blood film was reported as normal in 19.9\% while evidence of iron deficiency (18.5\%), early iron deficiency (32.5\%) and thalassemia trait with iron deficiency (29.5\%) were reported in the rest.

Serum ferritin level was available for 417 children with hemoglobin less than $12 \mathrm{~g} / \mathrm{dl}$. Mean ferritin level was 63.7 microgram/l. Only $0.5 \%$ had depleted iron stores. A multiple regression was performed for serum ferritin and $\mathrm{R}^{2}$ was 0 . $123(p<0.001)$. Area under the curve for serum ferritin and anemia was 0.436 .

Conclusion: Anemia among rural primary school children in NCP cannot be well explained by routinely assessed socioeconomic characteristics which mainly provide clues to access for food. Commonly used anemia related investigations have low validity in detecting and explaining anemia in this population. Since behavioral factors have been shown to affect nutrition of younger children in Sri Lanka, studying weather behaviors are related to anemia in primary school children is important. Possible etiologies including but not limited to nutritional deficiencies need to be studied further.

Keywords: Anemia, Primary school children, Sri Lanka, Anuradhapura, Polonnaruwa, North Central Province, Rural

\footnotetext{
* Correspondence: gayanishashikala.89@gmail.com

Maternal and Child Health Research Unit, Department of Community

Medicine, Faculty of Medicine and Allied Sciences, Rajarata University of Sri

Lanka, Saliyapura 50008, Sri Lanka
} 


\section{Background}

Anemia is a condition in which the number of red blood cells or their oxygen-carrying capacity is insufficient to meet physiologic needs [1]. Anemia affects around 305 million school age children globally [2]. It is estimated that about $50 \%$ of global anemia is due to iron deficiency [3].

Anemia has a variety of adverse health outcomes including mortality, depending on severity and characteristics of affected population. Anemia during infancy and childhood can impair immunity [4-7]. Anemia, specially iron deficiency anemia affects cognitive performances [8] and school performances in children [9-11]. It is also suggested that anemia increases the heavy metal absorption in children [12]. It affects the exercise tolerance [13] and hormonal regulation in adults [14].

Anemia has been reported as a major child health issue among Sri Lankan children since early $19^{\text {th }}$ century. Early, extensive studies on childhood anemia in Sri Lanka identified nutritional anemia as the main etiology, while thalassemia and malaria were also reported as additional causes [15-22]. Recent studies on anemia among Sri Lankan children are mainly focused on preschoolers and teenagers. These studies show a varying degree of anemia prevalence ranging from $15.1 \%$ [23] to 33\% [24] among children under 5 years of age and $11.1 \%$ [25] to $54.8 \%$ [26] among teenagers.

Anemia prevalence among Sri Lankan primary school children has been reported as $58 \%$ by National health and nutrition Survey (1995) [27], 84\% in Monaragala (1997) [28] and $52.7 \%$ in a hospital based study in Colombo district (2003) [29]. In all these studies, hemoglobin less than $12 \mathrm{~g} / \mathrm{dl}$ has been considered as the cut off. In a national wide survey in 2002, $12.1 \%$ of 9-10 years old children were found to be anemic [30]. Though studies are available on infants, preschool children and teenagers, resent studies on distribution and determinants of anemia among primary school children in Sri Lanka are limited. Moreover, health inequalities within the country have not been considered in most of the studies.

The national family health programme in Sri Lanka has implemented several anemia prevention interventions targeting different stages of life cycle. For an example, school medical inspection (SMI) programme is conducted nationally in all the schools. It includes providing iron and folate supplements, deworming treatment, and health education to students [31, 32]. National wide awareness programmes are conducted to prevent Thalassemia [33]. Even though malaria has been endemic in the past, indigenous cases of malaria have not been reported in Sri Lanka since 2012 [34]. With health interventions and rapid socioeconomic changes taking place in the country, the epidemiology of childhood anemia can be expected to be changed significantly, thus requiring further investigations on underlying causes.
We previously reported that anemia prevalence among rural primary school children in North Central Province (NCP), Sri Lanka was $17.1 \%$ and mean hemoglobin level is $12.2 \mathrm{~g} / \mathrm{dl}(\mathrm{SD}=0.89)$ [35]. Hemoglobin level less than $11.5 \mathrm{~g} / \mathrm{dl}$ was used as the cut off; as recommended by the WHO for 5-11 years old children living at altitudes of less than $1000 \mathrm{~m}$ [36]. Initial analysis has shown that the prevalence declined with age in both sexes [35]. Purpose of the present paper is to determine modifiable factors associated with childhood anemia in NCP in order to plan evidence based public health interventions.

\section{Methods}

This study was a part of a large study on nutritional status of school children in NCP. Detailed methodology of the original study is published elsewhere [35]. A summary is presented here.

The two districts in NCP; Anuradhapura and Polonnaruwa have estimated midyear populations of 883000 and 415000 respectively [37]. In year 2012/2013 mean household income per month was 36632 Rupees (243 USD) and poverty headcount index (the percentage of population living below the official poverty line) was $7.3 \%$ [38]. Out of 802 schools in the province, 701 (with a total student population of 93243 ) are considered as rural schools.

Population for this school based cross sectional study was 60-131 months old children, studying in rural schools in the NCP. A multi stage cluster sampling with probability proportionate to the size was used to select 100 rural schools. Maximum of 50 students per each school were enrolled using a simple random sampling technique. Socio-demographic information was obtained from a self-administered questionnaire sent to parents/ guardians through school principals prior to sample collection. Response rate was $97.6 \%(n=4521)$. Anthropometric measurements were obtained by trained medical graduates and laboratory samples were collected by trained nurses. Investigation reports were obtained from a commercial diagnostic laboratory with external quality control procedures. Further details on study design, including study setting, study population, sampling method, data collection tools and data collection are described in the previous paper [35].

IBM SPSS version 20 was used for data analysis. First, mean hemoglobin levels and anemia prevalence between different groups were compared using independent sample $t$ test or one way analysis of variance (ANOVA). Standard multiple regression was performed including hemoglobin as the dependent variable. District (Anuradhapura, Polonnaruwa), Sex and Ethnicity (Sinhala, Muslim) were entered as binary variables. Age, average monthly income of the family, Body Mass Index (BMI), maternal and paternal education (last grade passed at school) 
Table 1 Characteristics of study participants

\begin{tabular}{|c|c|c|}
\hline & Number & Percent \\
\hline \multicolumn{3}{|l|}{ District } \\
\hline Anuradhapura & 2480 & 56.2 \\
\hline Polonnaruwa & 1932 & 43.8 \\
\hline \multicolumn{3}{|l|}{ Sex } \\
\hline Males & 2228 & 50.8 \\
\hline Females & 2168 & 49.1 \\
\hline \multicolumn{3}{|l|}{ Ethnicity } \\
\hline Sinhala & 3704 & 84.0 \\
\hline Muslim & 384 & 8.7 \\
\hline Tamil & 6 & 0.1 \\
\hline \multicolumn{3}{|l|}{ Education division } \\
\hline Kabathigollawa & 713 & 16.2 \\
\hline Galenbindunuwewa & 514 & 11.7 \\
\hline Anuradhapura & 379 & 8.6 \\
\hline Thabuththegama & 502 & 11.4 \\
\hline Dibulagala & 538 & 12.2 \\
\hline Kekirawa & 372 & 8.4 \\
\hline Higurakgoda & 838 & 19.0 \\
\hline Polonnaruwa & 556 & 12.6 \\
\hline \multicolumn{3}{|c|}{ No. of children in the family } \\
\hline Less than 3 & 2474 & 61.2 \\
\hline 3 or more & 1567 & 38.7 \\
\hline \multicolumn{3}{|c|}{ Average family income per day (\$) } \\
\hline$<\$ 1$ & 292 & 8.1 \\
\hline$\$ 1-2$ & 391 & 10.8 \\
\hline$\$ 2-3$ & 535 & 14.8 \\
\hline$\$ 3-4$ & 112 & 3.1 \\
\hline$\$ 4-8$ & 1558 & 43.0 \\
\hline$\$ 8-12$ & 593 & 16.4 \\
\hline$>\$ 12$ & 142 & 3.9 \\
\hline \multicolumn{3}{|l|}{ Father's education level } \\
\hline Primary & 762 & 19.2 \\
\hline Up to $O / L$ & 2737 & 69.0 \\
\hline Above $\mathrm{O} / \mathrm{L}$ & 469 & 11.8 \\
\hline \multicolumn{3}{|l|}{ Mother's education level } \\
\hline Primary & 616 & 15.3 \\
\hline Up to O/L & 2732 & 67.9 \\
\hline Above $\mathrm{O} / \mathrm{L}$ & 675 & 16.8 \\
\hline \multicolumn{3}{|l|}{ Last worm treatment } \\
\hline Within 3 months & 2824 & 72.3 \\
\hline 3 to 6 months back & 893 & 22.8 \\
\hline Before 6 months & 191 & 4.8 \\
\hline \multicolumn{3}{|c|}{ Frequency of meat consumption } \\
\hline$<1^{\text {st }}$ Quartile & 1890 & 48.4 \\
\hline
\end{tabular}

Table 1 Characteristics of study participants (Continued)

\begin{tabular}{lll}
\hline $1^{\text {st }}$ to $2^{\text {nd }}$ Quartile & 953 & 24.4 \\
$2^{\text {nd }}$ to $3^{\text {rd }}$ Quartile & 476 & 12.2 \\
$>4^{\text {th }}$ Quartile & 584 & 15.0 \\
$\begin{array}{ll}\text { Frequency of green leaf consumption } \\
<1 \text { st Quartile }\end{array}$ & \\
$1^{\text {st }}$ to $2^{\text {nd }}$ Quartile & 1671 & 42.0 \\
$2^{\text {nd }}$ to $3^{\text {rd }}$ Quartile & 838 & 21.1 \\
$>4$ th Quartile & 654 & 16.5 \\
\hline
\end{tabular}

and number of children in the family were entered as quantitative variables. When the last worm treatment was given (within less than one month, within one month to three months, within three to six months, within six to twelve months and more than 12 months back) was entered as a categorical variable. Average number of meals containing meat and green leaves per week were binned to quartiles due to considerable number of unrealistic values reported by parents.

Results of peripheral blood film were analyzed using ANOVA.

Another standard multiple regression was performed including serum ferritin as the dependent variable. Independent variables were entered similar to as for hemoglobin except for the omission of district and addition of hemoglobin. Hemoglobin was entered as a quantitative variable.

Preliminary tests were performed for linearity, multicolinearity and normality for both regressions.

\section{Results}

Hemoglobin level was available for 4412 out of 4521 children in the original sample (see Table 1).

No significant difference in anemia prevalence (Pearson Chi-square $0.819, p=0.365$ ) or mean hemoglobin level $(t=-1.042, p=0.297)$ was observed between males and females. This was true for both Anuradhapura and Polonnaruwa districts individually and among ethnic Sinhalese and Muslims (Table 2).

Mean hemoglobin levels were significantly different between Sinhalese and Muslims $(t=-1.996, p=0.047)$ (Table 2).

The education divisions in Polonnaruwa district (Polonnaruwa, Hingurakkgoda and Dimbulagala) had lower prevalence of anemia compared to Anuradhapura divisions. Children from families with less than three children had higher mean hemoglobin level $(p=$ 0.016) compared to children from families with three or more children. Mean hemoglobin level increased with increased education level of father $(p=0.001)$ and mother $(p=0.005)$. Mean hemoglobin levels were not significantly different between children with different average family 
Table 2 Comparison of anemia prevalence and mean hemoglobin concentration between males and females across districts and ethnicities

\begin{tabular}{|c|c|c|c|c|c|c|c|}
\hline & & & \multirow{2}{*}{$\begin{array}{l}\text { Anemia } \\
\text { prevalence } \\
(\%)\end{array}$} & \multicolumn{4}{|c|}{ Hemoglobin (g/dl) } \\
\hline & & & & Mean & SD & t value & $p$ value \\
\hline \multirow[t]{4}{*}{ District } & Anuradhapura & Male & $20.0(N=253)$ & 12.07 & 0.94 & -0.802 & 0.423 \\
\hline & & Female & $20.2(N=245)$ & 12.10 & 0.86 & & \\
\hline & Polonnaruwa & Male & $14.4(\mathrm{~N}=139)$ & 12.32 & 0.88 & -0.545 & 0.586 \\
\hline & & Female & $11.8(\mathrm{~N}=113)$ & 12.34 & 0.85 & & \\
\hline \multirow[t]{6}{*}{ Ethnicity } & Sinhala & Male & $18.3(N=346)$ & 12.15 & 0.93 & -1.519 & 0.129 \\
\hline & & Female & $16.7(N=302)$ & 12.20 & 0.88 & & \\
\hline & & Total & $17.5(\mathrm{~N}=648)$ & 12.18 & 0.90 & & \\
\hline & Muslim & Male & $12.0(\mathrm{~N}=22)$ & 12.27 & 0.78 & 0.295 & 0.768 \\
\hline & & Female & $14.5(\mathrm{~N}=29)$ & 12.25 & 0.81 & & \\
\hline & & Total & $13.3(N=51)$ & 12.26 & 0.80 & & \\
\hline
\end{tabular}

income levels $(p=0.194)$ or across quartiles of parent reported frequency of meat $(p=0.559)$ or green leaf $(p=$ 0.864 ) consumption per week (Table 3 ).

No significant difference in mean hemoglobin level was observed between groups who had received worm treatment within last three months, within three to six months or more than six months back ( $p=$ 0.337 )(Table 3). However, when groups who had received worm treatment less than and more than one month back were compared, mean hemoglobin level was higher in the former group $(\mathrm{t}=3.413, p=0.001)$.

There was a week positive correlation between hemoglobin and weight for age $(r=.079, p<0.001)$, height for age $(r=0.041, p=0.007)$ and BMI for age $(r=$ $0.062, p<0.01)$.

A standard multiple regression was performed with hemoglobin as the dependent variable. $\left(\mathrm{R}^{2}=0.042, p<\right.$ 0.001) (Table 4). Preliminary tests were conducted for linearity, multicolinearity, and normality. Maternal education showed a strong colinearity with paternal education $(r=0.821, p<0.001)$ but both variables were allowed in the model since influence on each other practically is not likely. None of the variables had tolerance (1-R) less than 0.1 and Variance Influencing Factor was also less than 10 in all variables.

District, age, timing of worm treatment and BMI for age uniquely contributed $1.12 \%, 1.19 \%, 0.13 \%$ and $0.26 \%$ respectively to changes in hemoglobin level.

Peripheral blood film analyses were available for 146 children with anemia (Table 5).

When Post-Hoc tests were performed, groups having iron deficiency anemia (IDA) and thalassemia trait with iron deficiency (TT with ID) were having significantly lower mean hemoglobin levels than those who were reported as normal or having early iron deficiency (EID) ( $p<0.0001$ in all instances). There were no significant differences in mean hemoglobin level between children with IDA and TT with ID $(p=0.98)$ and between children with normal peripheral blood film analysis and EID $(p=0.66)$. Mean serum ferritin levels were not different between these groups $(F=1.5, p=0.22)$.

Serum ferritin reports were available for 417 out of 674 children in Polonnaruwa who had hemoglobin less than $12 \mathrm{~g} / \mathrm{dl}$. Out of them, 199 were anemic. Mean S. Ferritin level was 63.7 microgram/l $(\mathrm{SD}=37.6)$. Only $0.5 \%(N=2)$ had depleted iron stores (WHO recommended cutoff of Serum ferritin less than 15 microgram/l was used [39]).

A standard multiple regression was performed with $\mathrm{S}$. ferritin when hemoglobin was less than $12 \mathrm{~g} / \mathrm{dl}$ as the dependent variable (Table 6$). \mathrm{R}^{2}$ was $0.123(p<0.001)$. Only hemoglobin, average monthly income of family, sex, frequency of meat consumption and number of children in the family were contributing significantly to changes in serum ferritin.

When Receiver operated curve (ROC) was drawn for serum ferritin and anemia area under the curve was 0.436 (Fig. 1).

\section{Discussion}

This is the largest reported study available in the literature on childhood anemia in a single province in Sri Lanka. The study design enabled us to produce generalizable data on this rural population as a case study on anemia among primary school children in rural Sri Lanka. This study may be representing the changes in determinants of childhood anemia in low and middle income countries undergoing rapid epidemiological transition. Further, the study provides important clues about the impact of health inequalities within the country and the rural population itself on childhood nutrition. 
Table 3 Mean hemoglobin level and prevalence of anemia among rural primary school children in North Central Province, Sri Lanka

\begin{tabular}{|c|c|c|c|c|}
\hline & \multirow{2}{*}{$\begin{array}{l}\text { Anemia } \\
\text { prevalence \% }\end{array}$} & \multicolumn{3}{|c|}{ Hemoglobin } \\
\hline & & $\overline{M e a n}$ & SD & Significance \\
\hline \multicolumn{5}{|l|}{ Educational division } \\
\hline Kabathigollawa & $23.1(\mathrm{~N}=165)$ & 12.02 & 0.95 & \multirow[t]{8}{*}{$F=16.12, p=0.001$} \\
\hline Galenbindunuwewa & $21.4(N=110)$ & 12.03 & 0.92 & \\
\hline Anuradhapura & $17.7(\mathrm{~N}=67)$ & 12.08 & 0.84 & \\
\hline Thabuththegama & $20.5(\mathrm{~N}=103)$ & 12.12 & 0.90 & \\
\hline Dibulagala & $14.3(\mathrm{~N}=77)$ & 12.20 & 0.81 & \\
\hline Kekirawa & $14.5(\mathrm{~N}=54)$ & 12.22 & 0.83 & \\
\hline Higurakgoda & $13.0(\mathrm{~N}=109)$ & 12.34 & 0.85 & \\
\hline Polonnaruwa & $12.2(\mathrm{~N}=68)$ & 12.42 & 0.92 & \\
\hline \multicolumn{5}{|c|}{ No. of children in the family } \\
\hline Less than 3 & $16.3(\mathrm{~N}=403)$ & 12.21 & 0.88 & \multirow[t]{2}{*}{$t=2.413, p=0.016$} \\
\hline 3 or more & $18.3(\mathrm{~N}=286)$ & 12.14 & 0.92 & \\
\hline \multicolumn{5}{|c|}{ Average family income per day $(\$)$} \\
\hline$<\$ 1$ & $20.2(N=59)$ & 12.15 & 0.89 & \multirow[t]{7}{*}{$F=1.444, p=0.194$} \\
\hline$\$ 1-2$ & $16.1(\mathrm{~N}=63)$ & 12.24 & 0.94 & \\
\hline$\$ 2-3$ & $16.8(N=90)$ & 12.17 & 0.92 & \\
\hline$\$ 3-4$ & $11.6(N=13)$ & 12.25 & 0.88 & \\
\hline$\$ 4-8$ & $17.8(\mathrm{~N}=278)$ & 12.15 & 0.88 & \\
\hline$\$ 8-12$ & $15.7(\mathrm{~N}=93)$ & 12.23 & 0.88 & \\
\hline$>\$ 12$ & $19.0(\mathrm{~N}=27)$ & 12.27 & 0.84 & \\
\hline \multicolumn{5}{|l|}{ Father's education level } \\
\hline Primary & $16.5(N=126)$ & 12.12 & 0.87 & \multirow[t]{3}{*}{$F=7.236, p=0.001$} \\
\hline Up to O/L & $17.6(N=483)$ & 12.19 & 0.90 & \\
\hline Above $\mathrm{O} / \mathrm{L}$ & $14.3(N=67)$ & 12.32 & 0.88 & \\
\hline \multicolumn{5}{|l|}{ Mother's education level } \\
\hline Primary & $17.4(N=107)$ & 12.13 & 0.88 & \multirow[t]{3}{*}{$F=5.330, p=0.005$} \\
\hline Up to O/L & $17.5(\mathrm{~N}=477)$ & 12.17 & 0.91 & \\
\hline Above $\mathrm{O} / \mathrm{L}$ & $15.4(N=104)$ & 12.28 & 0.85 & \\
\hline \multicolumn{5}{|l|}{ Last worm treatment } \\
\hline Within 3 months & $15.9(\mathrm{~N}=449)$ & 12.21 & 0.87 & \multirow[t]{3}{*}{$F=1.087, p=0.337$} \\
\hline 3 to 6 months back & $19.0(N=170)$ & 12.16 & 0.92 & \\
\hline Before 6 months & $15.7(\mathrm{~N}=30)$ & 12.17 & 0.86 & \\
\hline \multicolumn{5}{|c|}{ Frequency of meat consumption } \\
\hline$<1^{\text {st }}$ Quartile & $17.5(N=331)$ & 12.18 & 0.91 & \multirow[t]{4}{*}{$F=0.689, p=0.559$} \\
\hline $1^{\text {st }}$ to $2^{\text {nd }}$ Quartile & $15.6(N=149)$ & 12.21 & 0.88 & \\
\hline $2^{\text {nd }}$ to $3^{\text {rd }}$ Quartile & $18.3(\mathrm{~N}=87)$ & 12.14 & 0.89 & \\
\hline$>4^{\text {th }}$ Quartile & $18.2(N=106)$ & 12.19 & 0.88 & \\
\hline \multicolumn{5}{|c|}{ Frequency of green leaf consumption } \\
\hline$<1$ st Quartile & $16.8(N=281)$ & 12.20 & 0.91 & \multirow[t]{4}{*}{$F=0.247, p=0.864$} \\
\hline $1^{\text {st }}$ to $2^{\text {nd }}$ Quartile & $17.1(N=143)$ & 12.17 & 0.96 & \\
\hline $2^{\text {nd }}$ to $3^{\text {rd }}$ Quartile & $17.4(N=114)$ & 12.17 & 0.85 & \\
\hline$>4$ th Quartile & $17.4(N=141)$ & 12.18 & 0.84 & \\
\hline
\end{tabular}


Table 4 Multiple regression for hemoglobin in rural primary school children in the NCP, Sri Lanka

\begin{tabular}{|c|c|c|c|c|c|c|}
\hline Variable & $r^{1}$ & $p^{1}$ & $\mathrm{~N}$ & Beta & $p^{2}$ & $r^{2}$ \\
\hline District & 0.134 & 0.000 & 4412 & 0.114 & 0.000 & 0.106 \\
\hline Sex & 0.016 & 0.149 & 4396 & 0.009 & 0.607 & 0.009 \\
\hline Ethnicity & 0.028 & 0.036 & 4088 & 0.023 & 0.197 & 0.022 \\
\hline Age (days) & 0.139 & 0.000 & 4412 & 0.140 & 0.000 & 0.139 \\
\hline Father's education & 0.056 & 0.000 & 3968 & 0.037 & 0.202 & 0.021 \\
\hline Mother's education & 0.049 & 0.001 & 4023 & -0.016 & 0.586 & -0.009 \\
\hline Average monthly income of family & 0.013 & 0.217 & 3623 & 0.010 & 0.548 & 0.010 \\
\hline Number of children in family & -0.015 & 0.171 & 4041 & -0.028 & 0.113 & -0.026 \\
\hline Frequency of green leaf consumption & -0.008 & 0.307 & 3975 & -0.019 & 0.281 & -0.018 \\
\hline Frequency of meat consumption & 0.001 & 0.485 & 3903 & 0.011 & 0.542 & 0.010 \\
\hline Worm treatment & -0.041 & 0.006 & 3908 & -0.039 & 0.026 & -0.037 \\
\hline BMI for age & 0.062 & 0.000 & 4328 & 0.052 & 0.002 & 0.051 \\
\hline
\end{tabular}

$\mathrm{r}$ - Pearson correlation, $\mathrm{p}^{1}$ - Significance of Pearson correlation, $\mathrm{N}$ - Number, Beta - Standardized Coefficient, $\mathrm{p}^{2}$ - Significance of standardized coefficient, $\mathrm{r}^{2}$

-Part Correlation

A significant difference was observed between the two districts showing subnational variations in anemia prevalence. This difference in hemoglobin level among children in two districts was an unexpected finding and it was independent from other factors such as differences in income, ethnic distribution, and parental education between the two districts. According to the demographic and health survey (DHS) 2006/2007 the lowest prevalence of anemia among under five children in Sri Lanka was reported in Polonnaruwa (15.2\%) while a higher prevalence (31.0\%) was reported in Anuradhapura [24]. Since the current study was conducted in 2014, population from which this study sample was driven may considerably overlaps with the 6 to 59 months old population studied in DHS 2007. However, according to national nutrient and micronutrient survey (NNMS) 2012, anemia prevalence in 6-59 months old children was lower in Anuradhapura (16.2\%) than in Polonnaruwa (21.5\%) [23]. The observed difference in anemia prevalence between the two districts in two time points may be due to a cohort effect which needs further investigation.
Sex doesn't contribute to differences in hemoglobin level in this study population. No difference in mean hemoglobin level was observed among males and females, in either districts or among different ethnicities (Sinhala and Muslim). Minimal discrimination against female child, as compared to some cultures in the region could be a major contributory factor for this observation. However according to previous studies, males were having higher anemia prevalence among 659 months old children [23] whereas females were having the higher prevalence among teenagers; specially after menarche [26].

An association between deworming and anemia has been described in Sri Lanka. A study in 2002 showed that prevalence of intestinal helminthes among a national representative sample of Sri Lankan primary school children was $6.9 \%$ [30]. Worm treatment is provided to students during SMI programme and based on routine data, SMI coverage was $85.7 \%$ in Anuradhapura and $80.9 \%$ in Polonnaruwa districts [40]. In current study $95.4 \%$ of children had received worm treatment within last six months. Considering that shorter intervals after deworming was associated with better

Table 5 Results of peripheral blood film analyses of anemic rural primary school children in NCP

\begin{tabular}{|c|c|c|c|c|c|c|}
\hline \multirow[t]{2}{*}{ Reporting on peripheral blood film } & \multirow{2}{*}{$\begin{array}{l}\text { Mild } \\
\text { anemia } \\
(\%)\end{array}$} & \multirow{2}{*}{$\begin{array}{l}\text { Moderate } \\
\text { anemiab } \\
(\%)\end{array}$} & \multirow[t]{2}{*}{ Total* $(\%)$} & \multicolumn{3}{|c|}{ Hemoglobin $(\mathrm{g} / \mathrm{dl})$} \\
\hline & & & & Mean & SD & $F(p)$ \\
\hline Normal & $28(36.8 \%)$ & $1(1.4 \%)$ & 29 (19.9\%) & 11.21 & 0.17 & $26.2(0.001)$ \\
\hline Iron deficiency anemia & $6(7.9 \%)$ & $21(30.0 \%)$ & $27(18.5 \%)$ & 10.37 & 0.80 & \\
\hline Early iron deficiency & $32(42.1 \%)$ & $15(21.4 \%)$ & 47 (32.2\%) & 11.08 & 0.26 & \\
\hline Thalassemia trait with iron deficiency & $10(13.2 \%)$ & 33 (47.1\%) & 43 (29.5\%) & 10.42 & 0.60 & \\
\hline
\end{tabular}

*No severe anemia cases (hemoglobin less than $8 \mathrm{~g} / \mathrm{dl}$ ) were present

ahemoglobin 11-11.4 g/dl [36]

bemoglobin 8-10.9 g/dl [36] 
Table 6 Multiple linear regression for ferritin in rural primary school children in Polonnaruwa district who have hemoglobin levels less than $12 \mathrm{~g} / \mathrm{dl}$

\begin{tabular}{|c|c|c|c|c|c|c|}
\hline & $r^{1}$ & $p^{1}$ & $\mathrm{~N}$ & Beta & $p^{2}$ & $r^{2}$ \\
\hline Hemoglobin & -0.241 & 0.000 & 417 & -0.248 & 0.000 & -0.244 \\
\hline Average monthly income of family & -0.131 & 0.006 & 359 & -0.136 & 0.008 & -0.134 \\
\hline Frequency of meat consumption & 0.114 & 0.013 & 384 & 0.134 & 0.014 & 0.125 \\
\hline Sex & -0.109 & 0.013 & 413 & -0.108 & 0.033 & -0.108 \\
\hline Mother's education & -0.080 & 0.057 & 397 & -0.081 & 0.362 & -0.046 \\
\hline Father's education & -0.064 & 0.103 & 389 & 0.033 & 0.710 & 0.019 \\
\hline Age (days) & 0.065 & 0.092 & 417 & 0.097 & 0.059 & 0.095 \\
\hline Frequency of green leaf consumption & 0.037 & 0.237 & 382 & -0.003 & 0.961 & -0.002 \\
\hline BMI for age & -0.003 & 0.477 & 403 & 0.025 & 0.627 & 0.024 \\
\hline Ethnicity & -0.002 & 0.488 & 405 & -0.029 & 0.593 & -0.027 \\
\hline Number of children in the family & 0.098 & 0.025 & 402 & 0.082 & 0.120 & 0.078 \\
\hline Timing of warm treatment & 0.028 & 0.289 & 396 & 0.006 & 0.906 & 0.006 \\
\hline
\end{tabular}

$\mathrm{r}^{1}$ - Pearson correlation, $\mathrm{p}^{1}$ - Significance of Pearson correlation, $\mathrm{N}$ - Number, Beta - Standardized Coefficient, $\mathrm{p}^{2}$ - Significance of standardized coefficient, $\mathrm{r}^{2}$

-Part correlation

hemoglobin levels in this study, paying attention to control of transmission of intestinal helminthes can be viewed as important as periodical deworming.

In contrast to findings from most of the studies on childhood anemia in developing countries, economic status was not correlated with hemoglobin level in this population. Even in Sri Lanka, the NNMS has reported an association between monthly income and anemia in 6-59 months old children [23]. However, our study population is more homogenous compared to that of the

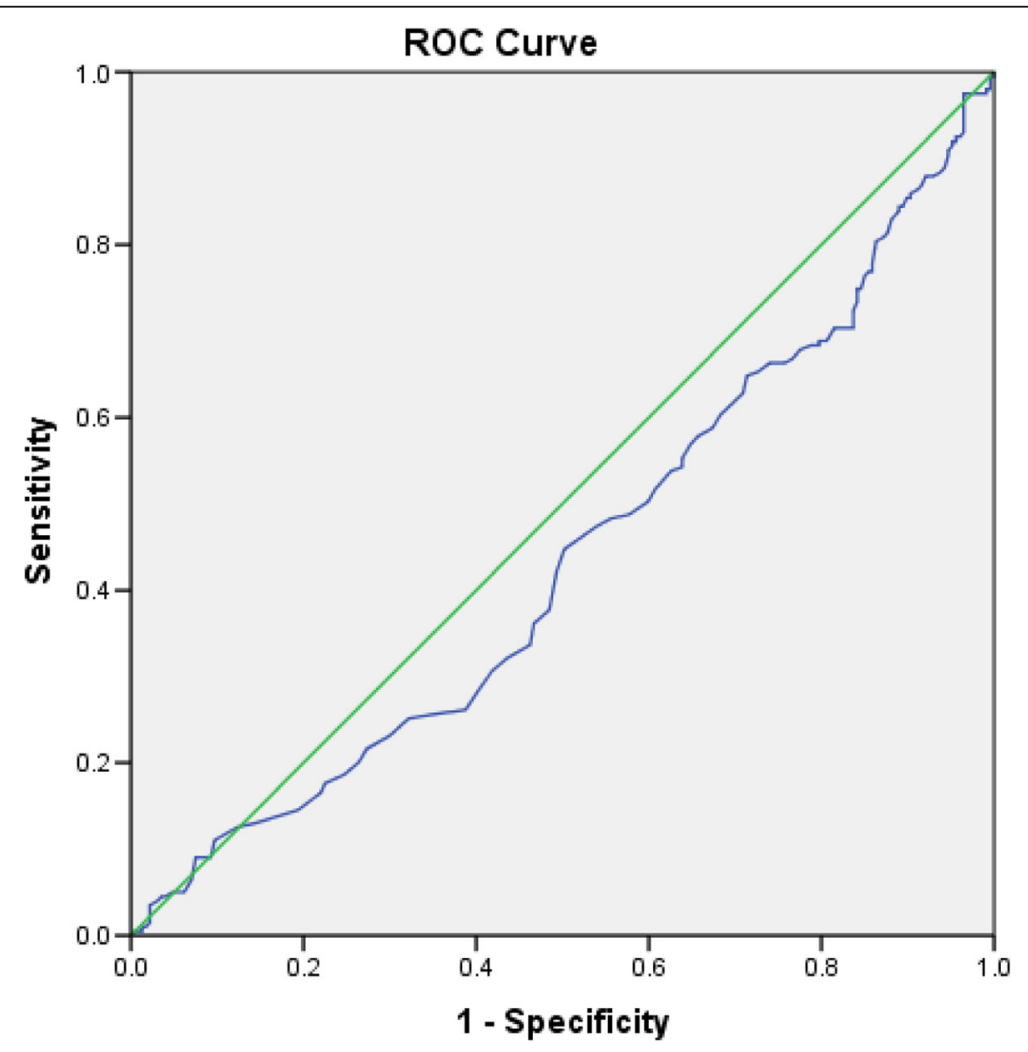

Diagonal segments are produced by ties.

Fig. 1 Receiver Operated Curve for serum ferritin level and anemia in rural primary school children in NCP with hemoglobin less than $12 \mathrm{~g} / \mathrm{dl}$ 
national survey and therefore can be assumed to provide more generalizable data on rural community. Access to food was not observed as a significant contributory factor in this study. This statistical model could explain only $4.2 \%$ of the change in hemoglobin level of 60 131 months old children in rural Sri Lanka. Therefor hemoglobin has to be affected by factors other than socio, economic and demographic characteristics analyzed in this study. Evidence are appearing that certain behaviors of caregivers affect the nutrition state of infants and young children in Sri Lanka [41-44]. Behavioral factors may be affecting hemoglobin level of primary school children as well.

However, this study provides limited information on food consumption patterns and even less so on the determinants of such behaviors. A more structured assessment of them needs to be carried out in further studies in order to find out and modify factors contributing to anemia among primary school children in Sri Lanka.

Observations on results of peripheral blood film analysis raise questions on validity of it as an investigation supplementing the diagnosis and explanation of anemia. They are heavily used in day today clinical practice for this purpose and if there are issues on accuracy it might affect the accuracy of clinical decisions. These observations are also suggestive that it may be worth to carry out further research to establish whether or not an alternative cutoff hemoglobin level is more suitable to define anemia in this population.

Iron deficiency is considered as the commonest cause of anemia among children specially in low and middle income countries [3]. Epidemiological studies and interventions in these settings usually focus on determinants of iron deficiency or broadly, nutritional anemias. In this study, only two $(0.5 \%)$ children out of 417 had depleted iron stores. It seems to be an underestimation, compared to the prevalence of anemia. Previous studies also have reported that iron deficiency may not be the leading cause of anemia in rural Sri Lanka [28]. Prevalence of other micronutrient deficiencies (e.g. Folate) have been described among Sri Lankan children which may be a cause for anemia in this sample also [26, 45]. However, higher prevalence of iron deficiency was predicted by peripheral blood film analysis of the current sample. Higher prevalence of depleted iron stores in preschoolers and adolescents have been identified in other parts of the country $[26,45,46]$. Serum Ferritin depends on other factors such as presence of haemoglobinopathies [47] and inflammation [48]. According to peripheral blood film analyses $29.5 \%$ anemic children were having thalassemia trait with iron deficiency. Some studies even argue that serum ferritin should not be used alone to determine iron status [49]. Faulty estimation of S. Ferritin can occur due to variety of reasons also [50].
Area under the curve being 0.436 also supports that serum ferritin is a poor test with regards to predicting anemia in this study sample.

Conclusive evidence on etiological basis of anemia could not be obtained from peripheral blood film analysis or serum ferritin estimations. Therefore, estimation of iron stores and identification of hemoglobinopathies need to be carried out using more reliable tests.

As the study was based in rural primary schools, results may not be generalizable to children attending other schools with higher resources and access. Even though small in percentage (net school enrolment is 99.8\% in rural areas [51]), children who are not attending school are also left out in this study. Data about food consumption patterns were not obtained using validated food frequency questionnaires. A complete picture about population iron stores cannot be derived as serum ferritin estimates were available only for children from Polonnaruwa who had hemoglobin less than $12 \mathrm{~g} / \mathrm{dl}$. Comparing serum ferritin levels in children from the two districts could have provided important clues to the cause of cohort effect resulting in lower anemia prevalence in Polonnaruwa. If inflammatory conditions at the time of sample collection could be identified by testing for inflammatory markers interpretation of ferritin levels would have been more accurate.

Unique contribution from this study

This is the largest reported study available in the literature on childhood anemia in a single province in Sri Lanka.

This is a school based study investigating into prevalence and determinants of anemia among rural primary school children, which has not been studied thoroughly in the past.

The study provides important clues about how health inequalities within the country and the rural population itself affect childhood nutrition.

This study may be representing the changes in determinants of childhood anemia in low and middle income countries undergoing rapid epidemiological transition

\section{Conclusion}

Anemia is still a public health problem among primary school children in NCP. It cannot be well explained by routinely assessed demographic or socio economic characteristics which mainly give clues to access for food. Commonly used anemia related investigations are having a low validity in detecting and explaining anemia in this population. Since evidence on behavioral factors affecting the nutrition of infants and young children are emerging in Sri Lanka, studying the effect of behaviors on anemia among primary school children will be important. Possible etiologies including but not limited to nutritional deficiencies needs to be studied further. 


\section{Abbreviations}

ANOVA: Analysis of variance; BMl: Body mass index; DHS: Demographic and health survey; EID: Early iron deficiency; IDA: Iron deficiency anemia; NCP: North Central Province; NNMS: National nutrient and micronutrient survey; ROC: Receiver operated curve; SMI: School medical inspection; ПT: Thalassemia trait; WHO: World Health Organization

\section{Acknowledgement}

Former National Nutrition Coordinator Dr. Lalith Chandradasa commissioned this study.

\section{Funding}

First phase of this study was funded through a grant from Sri Lankan country office of World Health Organization.

\section{Availability of data and material}

Raw data from this study will be available for researchers/implementers upon request from the senior author (SBA).

\section{Authors' contribution}

SBA conceived and designed the study, involved in analysis and interpretation of data and manuscript writing. GSA involved in field work, database preparation, analysis and interpretation of data and prepared the draft of manuscript. NPGCRN develop the protocol, coordinated the fieldwork and data management, and helped in manuscript writing. TCA involved in design, data interpretation and manuscript writing. All authors read and approved the final manuscript.

\section{Competing interests}

The authors declare that they have no competing interests.

\section{Consent for publication}

Not applicable

\section{Ethics approval and consent to participation}

Informed written consent was obtained from parents prior to data collection. Ethical clearance was obtained from the Ethics Review Committee of Faculty of Medicine and Allied Sciences, Rajarata University of Sri Lanka.

\section{Publisher's Note}

Springer Nature remains neutral with regard to jurisdictional claims in published maps and institutional affiliations.

Received: 13 October 2016 Accepted: 18 March 2017

Published online: 27 March 2017

\section{References}

1. WHO. Anaemia [Internet]. World Heal. Organ. 2015. Available from: http:// www.who.int/topics/anaemia/en/. Accessed 19 Feb 2016.

2. World Health Organisation. Worldwide prevalence of anaemia 1993-2005 WHO global database on anaemia. Benoist B de, McLean $E_{1}$ Ines $E_{1}$ Cogswell M, editors. Geneva: World Health Organization; 2008. Available from: http:// apps.who.int/iris/bitstream/10665/43894/1/9789241596657_eng.pdf. Accessed 10 Aug 2016

3. WHO, United Nations Children's Fund, United Nations University. Iron Deficiency Anaemia Assessment, Prevention, and Control: A guide for programme managers. 2001. Available from: http://apps.who.int/iris/ bitstream/10665/66914/1/WHO_NHD_01.3.pdf?ua=1. Accessed 10 Aug 2016.

4. Ramakrishnan K, Harish PS. Hemoglobin level as a risk factor for lower respiratory tract infections. Indian J Pediatr. 2006;73:881-3. Available from: http://link.springer.com/10.1007/BF02859279.

5. Thibault H, Galan P, Selz F, Preziosi P, Olivier C, Badoual J, et al. The immune response in iron-deficient young children: effect of iron supplementation on cell-mediated immunity. Eur J Pediatr. 1993;152:120-4. Available from: http://www.ncbi.nlm.nih.gov/pubmed/8444218.

6. Chandra RK. Reduced bactericidal capacity of polymorphs in iron deficiency. BMJ Group. 1973;48:864-6. Available from: http://www.ncbi.nlm.nih.gov/ pubmed/4761054

7. Abdel-Maks HM, Hasan KA, Helwa MA. Evaluation of Iron Deficiency Anemia as a Predisposing Factor in the Occurrence of Pneumonia in Children.
Trends Med Res. 2016;11:69-75. Available from: http://www.scialert.net/ abstract/?doi=tmr.2016.69.75.

8. Lozoff B, Jimenez E, Wolf AW. Long-term developmental outcome of infants with iron deficiency. N Engl J Med. 1991;325:687-94. Available from: http:// www.ncbi.nlm.nih.gov/pubmed/1870641.

9. Soemantri AG, Pollitt E, Kim I. Iron deficiency anemia and educational achievement. Am J Clin Nutr. 1985;42:1221-8. Available from: http://www. ncbi.nlm.nih.gov/pubmed/4072957.

10. Soemantri AG. Preliminary findings on iron supplementation and learning achievement of rural Indonesian children. Am J Clin Nutr. 1989;50:698-701. Available from: http://www.ncbi.nlm.nih.gov/pubmed/2773847.

11. Falkingham M, Abdelhamid A, Curtis P, Fairweather-Tait S, Dye L, Hooper L. The effects of oral iron supplementation on cognition in older children and adults: a systematic review and meta-analysis. Nutr J. 2010;9:4. Available from: http://www.ncbi.nlm.nih.gov/pubmed/20100340.

12. Khan DA, Ansari WM, Khan FA. Synergistic effects of iron deficiency and lead exposure on blood lead levels in children. World J Pediatr. 2011;7:1504. Available from: http://link.springer.com/10.1007/s12519-011-0257-9.

13. Edgerton VR, Ohira Y, Hettiarachchi J, Senewiratne B, Gardner GW, Barnard RJ. Elevation of hemoglobin and work tolerance in iron-deficient subjects. J Nutr Sci Vitaminol (Tokyo). 1981;27:77-86. Available from: http://www.ncbi. nlm.nih.gov/pubmed/7310552.

14. Demir C, Gökdeniz E, Dilek I. The effects of iron deficiency anemia on the thyroid functions Demir eksikliği anemisinin tiroid fonksiyonları üzerine etkisi. J Clin Exp Investig. 2010;1:156-60.

15. Nagaratnam N, Sukumaran PK. Thalassaemia in Ceylon. Acta Haematol. 1967; 38:209-18. Available from: http://www.ncbi.nlm.nih.gov/pubmed/4964889.

16. De Silva CC. Anemias of Ceylonese children. Isr J Med Sci. 1967;3:182-3. Available from: http://www.ncbi.nlm.nih.gov/pubmed/6030421.

17. De Silva CC, Fernando RP. Anemias of Ceylonese children. Isr J Med Sci. 2016;2 499-505. Available from: http://www.ncbi.nlm.nih.gov/pubmed/5966002.

18. De Silva CC. Common nutritional disorders of childhood in the tropics. Adv Pediatr. 1964;13:213-64. Available from: http://www.ncbi.nlm.nih.gov/ pubmed/14153773.

19. Rajasuriya K, Somasunderam M, Nagaratnam N. The aetiology of anaemia in Ceylon with special reference to protein malnutrition. J Trop Med Hyg. 1962; 65:219-29. Available from: http://www.ncbi.nlm.nih.gov/pubmed/13990552.

20. Rajasuriya K, Somasunderam M, Nagaratnam N, Fernando CF. Nutritional megaloblastic anaemias of Ceylon. J Trop Med Hyg. 1960;63:275-86. Available from: http://www.ncbi.nlm.nih.gov/pubmed/13739219.

21. Foy H, Kondi A. Anaemias of the Tropics, India and Ceylon. J Trop Med Hyg. 1958;61:27-47. Available from: http://www.ncbi.nlm.nih.gov/pubmed/13514841.

22. Vahlquist B. The anaemias of childhood. Ceylon Med J. 1952;1:128-34. Available from: http://www.ncbi.n/m.nih.gov/pubmed/13033053.

23. Jayatissa R, Gunathilaka M, Fernando D. National Nutrition and Micronutrient Survey 2012 Part I: Anaemia among children aged 6-59 months and nutritional status of children and adults. 2012.

24. Department of Census and Statistics. Demographic \& Health Survey 2006/ 07: Prevalence of Anaemia Among Children and Women in Sri Lanka. 2009.

25. Jayatissa R, Ranbanda RM. Prevalence of challenging nutritional problems among adolescents in Sri Lanka. Food Nutr Bull. 2006;27:153-60. Available from: http://www.ncbi.nlm.nih.gov/pubmed/16786981.

26. Hettiarachchi M, Liyanage C, Wickremasinghe R, Hilmers DC, Abrahams SA Prevalence and severity of micronutrient deficiency: a cross-sectional study among adolescents in Sri Lanka. Asia Pac J Clin Nutr. 2006;15:56-63. Available from: http://www.ncbi.nlm.nih.gov/pubmed/16500879.

27. Mudalige R, Nestel P. Combating Iron Deficiency 2. Prevalence of Anaemia in Sri Lanka. Ceylon J Med Sci. 1996;39:9-16.

28. Fernando SD, Paranavitane SR, Rajakaruna J, Weerasinghe S, Silva D, Wickremasinghe AR. The health and nutritional status of school children in two rural communities in Sri Lanka. Trop Med Int Heal. 2000;5:450-2. Available from: http://doi.wiley.com/10.1046/j.1365-3156.2000.00569.x.

29. de Silva A, Atukorala S, Weerasinghe I, Ahluwalia N. Iron supplementation improves iron status and reduces morbidity in children with or without upper respiratory tract infections: a randomized controlled study in Colombo, Sri Lanka. Am J Clin Nutr. 2003;77:234-41. Available from: http:// www.ncbi.nlm.nih.gov/pubmed/12499347.

30. Pathmeswaran A, Jayatissa R, Samarasinghe S, Fernando A, de Silva RP, Thattil RO, et al. Health status of primary schoolchildren in Sri Lanka. Ceylon Med J. 2005:50:46-50. Available from: http//www ncbi.nlm nih gov/ pubmed/16114767. 
31. Office of the Director of Health Services, Ministry of Health. Weekly Iron Folate Supplementation (WIFS) for School Children. Colombo 10: Ministry of Health; 2013. Available from: http://fhb.health.gov.lk/web/index.php?option= com_phocadownload\&view=category\&download=734: weekly-iron-folicacid-2013-onwards-english-pdf\&id=33:school-health\&start=16\&ltemid= 151\&lang=en.

32. School Health Promotion Programme. Colombo: School and Adolescent Health Unit Family Health Bureau, Health and Nutrition Division Ministry of Education; 2008.

33. Mudiyanse R, Senanayake M, Rathnayake R. "Safe Marriages" for Thalassaemia Prevention: A KAP Survey in Sri Lanka. Transl Biomed. 2015;6: 26. Available from: http://www.transbiomedicine.com/translationalbiomedicine/safe-marriages-for-thalassaemia-prevention-a-kapsurvey-in-srilanka.php?aid=7584.

34. Ministry of Health Nutrition and Indigenous Medicine Sri Lanka. Annual Health Bulletin 2014. 2016

35. Naotunna NPGCR, Dayarathna M, Maheshi H, Amarasinghe GS, Kithmini VS, Rathnayaka M, et al. Nutritional status among primary school children in rural Sri Lanka; a public health challenge for a country with high child health standards. BMC Public Health. 2017;17:57. Available from: http:// bmcpublichealth.biomedcentral.com/articles/10.1186/s12889-016-4001-1.

36. WHO Vitamin and Mineral Nutrition Information System. Haemoglobin concentrations for the diagnosis of anaemia and assessment of severity. 2011. Available from: http://www.who.int/vmnis/indicators/haemoglobin pdf. Accessed 1 Aug 2016.

37. Registrar general department SL. Mid-year Population Estimates by District and Sex 2013 - 2015. Available from: http://www.statistics.gov.Ik/PopHouSat/ VitalStatistics/MidYearPopulation/Mid-year population by district.pdf. Accessed 20 Aug 2016

38. Department of Census and Statistics. Poverty Indicators, Household Income and Expenditure Survey - 2012/13. 2015.

39. WHO. Serum ferritin concentrations for assessment of iron status and iron deficiency in populations. WHO Vitam. Miner. Nutr. Inf. Syst. Geneva; 2011. Available from: http://www.who.int/vmnis/indicators/serum_ferritin.pdf

40. Family Health Bureau Sri Lanka. Annual Report on Family Health. 2013.

41. Bandara T, Hettiarachchi M, Liyanage C, Amarasena S. Current infant feeding practices and impact on growth in babies during the second half of infancy. J Hum Nutr Diet. 2015;28:366-74. Available from: http://www.ncbi. nlm.nih.gov/pubmed/24976392

42. Perera PJ, Fernando M, Warnakulasuria T, Ranathunga N. Feeding practices among children attending child welfare clinics in Ragama $\mathrm{MOH}$ area: a descriptive cross-sectional study. Int Breastfeed J. 2011;6:18. Available from: http://www.ncbi.nlm.nih.gov/pubmed/22104029.

43. Agampodi TC. Responsive feeding: The missing link in child malnutrition in Sri Lanka. Sri Lanka J Child Heal. 2014;43:53-4.

44. SS S, Karunamuni N, Pwpwk P, Rmm R, Sb A, Tc A. Responsive feeding practices among caregivers in rural Anuradhapura; a missing component in infant feeding! Anuradhapura Med J. 2015;9:S04

45. Hettiarachchi M, Liyanage C. Coexisting micronutrient deficiencies among Sri Lankan pre-school children: a community-based study. Matern Child Nutr. 2012; 8:259-66. Available from: http://www.ncbinlm.nih.gov/pubmed/21166995.

46. Atukorala TM, de Silva LD. Iron status of adolescent females in three schools in an urban area of Sri Lanka. J Trop Pediatr. 1990;36:316-21. Available from: http://www.ncbi.nlm.nih.gov/pubmed/2280440.

47. Hoorfar H, Sadrarhami S, Keshteli AH, Ardestani SK, Ataei M, Moafi A. Evaluation of iron status by serum ferritin level in iranian carriers of beta thalassemia minor. Int J Vitam Nutr Res. 2008;78:204-7.

48. WHO, Center for Disease Control and Prevention. Assessing the Iron Status at the Population Level. 2nd ed. Geneva: World Health Organization; 2004

49. Madanat F, El-Khateeb M, Tarawaneh M, Hijazi S. Serum ferritin in evaluation of iron status in children. Acta Haematol. 1984:71:111-5. Available from: http://www.ncbi.nlm.nih.gov/pubmed/6421048. Accessed 25 Feb 2017.

50. Worwood M. Indicators of the iron status of populations: ferritin. Assess. iron status popuations Incl. Lit. Rev. 2nd ed. Geneva: World Health Organization; 2004. p. 31-74.

51. United Nations. Millennium Development Goals Country Report 2014: Sr Lanka [Internet]. 2015. Available from: http://www.lk.undp.org/content/ srilanka/en/home/library/mdg/sri-lanka-millennium-development-goalscountry-report-2014.html.

\section{Submit your next manuscript to BioMed Central and we will help you at every step:}

- We accept pre-submission inquiries

- Our selector tool helps you to find the most relevant journal

- We provide round the clock customer support

- Convenient online submission

- Thorough peer review

- Inclusion in PubMed and all major indexing services

- Maximum visibility for your research

Submit your manuscript at www.biomedcentral.com/submit
Ciomed Central 